\title{
Evidence for coupling between nitrile groups using DNA templates: A promising new method for monitoring structures with infrared spectroscopy
}

\author{
Amber T. Krummel and Martin T. Zanni* \\ University of Wisconsin-Madison, Department of Chemistry, 1101 University Ave., Madison,WI 53703 \\ zanni@chem.wisc.edu
}

\section{Supplemental Information}

Phosphoramidite Synthesis. Solid phase synthesis of the oligonucleotides used in this study required the phosphoramidite of 2'-deoxy-5-(trifluoromethyl)uridine to be synthesized. Thus, we converted the nucleoside to the dimethoxytrityl-protected phosphoramidite using the same methods described by Sigurdsson et $a l$ and the references therein.

Solid-Phase Synthesis and Conversion to Nitrile Labeled DNA. The nitrile labels were attached to the DNA by converting 2'-deoxy-5-(trifluoromethyl)uridine to 2'-deoxy-5-(cyano)uridine $\left(\mathrm{C}^{14} \mathrm{NdU}\right.$ or $\mathrm{C}^{15} \mathrm{NdU}$ ) during the standard cleavage and deprotection of the oligonucleotides from solid-phase supports. The conversion to $\mathrm{C}^{14} \mathrm{NdU}$ was carried out in the presence of $8.43 \mathrm{M}^{14} \mathrm{NH}_{4} \mathrm{OH}$ at $70^{\circ} \mathrm{C}$ for 16 hours. Since concentrated ammonium hydroxide is used in to convert the trifluoromethyl group on the uridine to the nitrile group, two nitrile tags are actually available to label the DNA. If ${ }^{15} \mathrm{~N}$ enriched ammonium hydroxide is used instead, the trifluoromethyl is converted to $\mathrm{C}^{15} \mathrm{~N}$. To generate $\mathrm{C}^{15} \mathrm{NdU}$ isotope labeled oligomers, the conversion was done in the presence of $6.0 \mathrm{M}{ }^{15} \mathrm{NH}_{4} \mathrm{OH}$ at $70^{\circ} \mathrm{C}$ for 24 hours. The $\mathrm{C}^{15} \mathrm{NdU}$ has the same spectral characteristics as the $\mathrm{C}^{14} \mathrm{NdU}$, only its IR absorbance is $\sim 25$ $\mathrm{cm}^{-1}$ shifted down in frequency from the $\mathrm{C}^{14} \mathrm{NdU}$ peak. 
In this study we used oligomers that contained the nitrile labels on the 5', the 3 ', or both ends of the oligomer. When incorporating the label at the 5' end, the DNA was synthesized using standard supports with the first nucleotide already attached to it. The Universal Support I was used when the label was incorporated at the 3' end of the sequences. All solid-phase supports were purchased from Glen Research Corporation and the synthesis and RP-HPLC purification of the oligonucleotides was carried out by the DNA Synthesis Laboratory at the University of Wisconsin Biotechnology Center. The sequences used are given in Table S1 along with their estimated solvent-dependent melting temperature (Tm). A schematic of the dsDNA constructs and relative positions of the nitrile tags is depicted in Figure S1. The sequences containing the nitrile labels are only complimentary to the template oligomer. The dsDNA constructs used in the experiments were designed to contain two sets of nitrile labels to double the nitrile absorption for each strand. The symmetry of DNA guarantees the same coupling strength for both sets of labels.

Table S1. DNA sequences and melting temperatures (Tm). $\mathrm{C}^{14} \mathrm{NdU}$ and $\mathrm{C}^{15} \mathrm{NdU}$ are designated as $\mathrm{U}^{\mathrm{C} 14 \mathrm{~N}}$ and $\mathrm{U}^{\mathrm{C} 15 \mathrm{~N}}$, respectively. OAK-30 is the template DNA.

\begin{tabular}{|l|l|l|l|}
\hline Name & Sequence $\left(5^{\prime} \rightarrow 3^{\prime}\right)$ & Length & Tm $\left(\mathrm{H}_{2} \mathrm{O}\right)$ \\
\hline OAK-25 & AAC GCC CCG CCC CU ${ }^{\mathrm{C} 14 \mathrm{~N}}$ & 14 & $64^{\circ} \mathrm{C}$ \\
\hline OAK-26 & $\mathrm{U}^{\mathrm{C} 15 \mathrm{~N}}$ CC CCG CAT ACG GCC CCU ${ }^{\mathrm{C} 15 \mathrm{~N}}$ & 17 & $69^{\circ} \mathrm{C}$ \\
\hline OAK-27 & $\mathrm{U}^{\mathrm{C14N}} \mathrm{CC}$ CCG CCC CGC AA & 14 & $64^{\circ} \mathrm{C}$ \\
\hline OAK-28 & $\mathrm{U}^{\mathrm{C} 15 \mathrm{~N}} \mathrm{CC}$ CCG CCC CGC AA & 14 & $64^{\circ} \mathrm{C}$ \\
\hline OAK-29 & TCC CCG CAT ACG CCC CT & 17 & $69^{\circ} \mathrm{C}$ \\
\hline OAK-30 & $\begin{array}{l}\text { TTG CGG GGC GGG GAA GGG GCG TAT } \\
\text { GCG GGG AAG GGG CGG GGC GTT }\end{array}$ & 45 & N/A \\
\hline
\end{tabular}


Figure S1. Schematic of the DNA constructs used in this study.

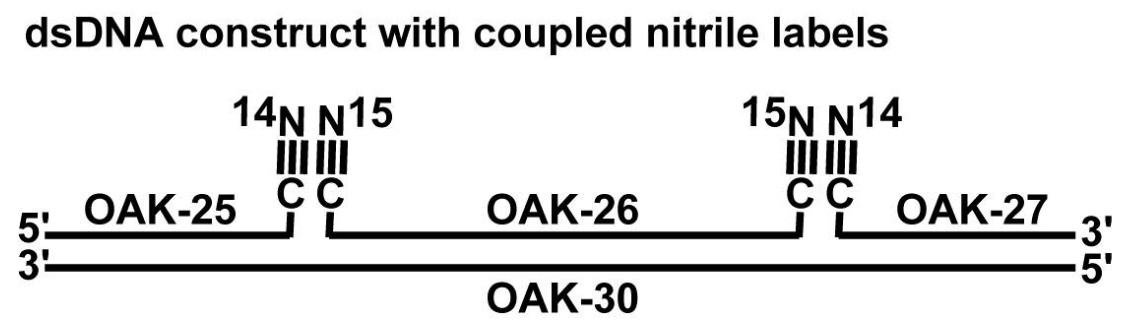

Control 1. single stranded DNA in $\mathrm{H}_{2} \mathrm{O}$

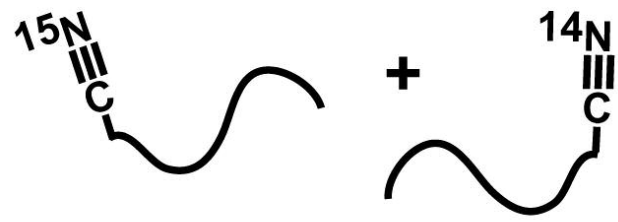

Control 2. dsDNA construct with uncoupled nitrile labels

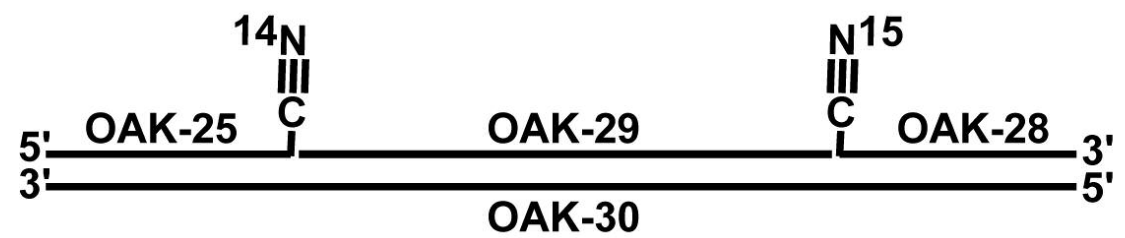

FTIR and UVCD Measurements. Purified samples were either reconstituted in $\mathrm{H}_{2} \mathrm{O}$ or a solvent mixture containing $80 \%$ Trifluoroethanol (TFE)/20\% $\mathrm{H}_{2} \mathrm{O}(\mathrm{v} / \mathrm{v})$. The secondary structures of the doublestranded DNA (dsDNA) were determined by UVCD measurements. The duplex DNA was B-form in $\mathrm{H}_{2} \mathrm{O}$, and A-form in the TFE/ $\mathrm{H}_{2} \mathrm{O}$ solvent. The UVCD spectra of the ssDNA, B-form dsDNA, and Aform dsDNA are shown in Figure S2. When the DNA is in the TFE/ $\mathrm{H}_{2} \mathrm{O}$ solvent, the CD spectrum contains a positive peak at $246 \mathrm{~nm}$ and the zero-crossing is at $260 \mathrm{~nm}$, as expected for A-form DNA. When the DNA is in $\mathrm{H}_{2} \mathrm{O}$, the $\mathrm{CD}$ spectrum exhibits a positive peak at $280 \mathrm{~nm}$, a negative peak of equal intensity at $250 \mathrm{~nm}$, and the zero-crossing is at $260 \mathrm{~nm}$; these features are indicative of B-form DNA. ${ }^{1}$ All infrared spectra were recorded on a Vertex 70 FTIR spectrometer (Bruker Optics, Inc.). Samples were held between two $\mathrm{CaF}_{2}$ plates with a 25 or $56 \mu \mathrm{m}$ spacer. The spectra of samples in $\mathrm{H}_{2} \mathrm{O}$ were obtained at ambient temperature $\left(22^{\circ} \mathrm{C}\right)$ and $10^{\circ} \mathrm{C}$ in $\mathrm{TFE} / \mathrm{H}_{2} \mathrm{O}$. The samples were held at these 
temperatures using a Temperature Control Cell (TFC-M25-3, Harrick Scientific Products, Inc.). The DNA samples ranged from $5 \mathrm{mM}$ to $10 \mathrm{mM}$ in strand concentration.

Figure S2. CD spectra of B-form dsDNA in $\mathrm{H}_{2} \mathrm{O}$ and A-form dsDNA in TFE/ $\mathrm{H}_{2} \mathrm{O}$.

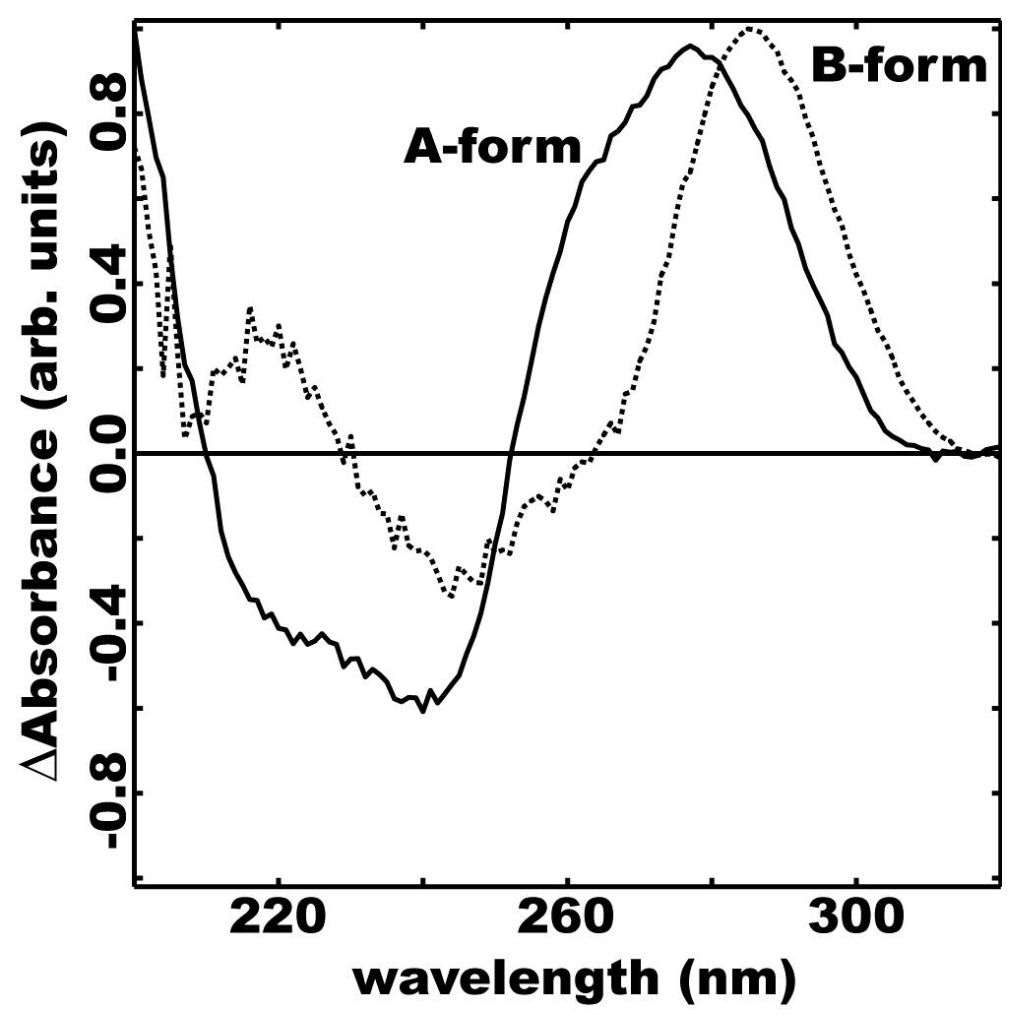

FTIR Experiments. In this study dsDNA constructs were probed in two solvent systems, $\mathrm{H}_{2} \mathrm{O}$ and a $\mathrm{TFE} / \mathrm{H}_{2} \mathrm{O}$ solvent mixture. The frequencies and relative intensities for the nitrile labels in each DNA sample are given in Table S2. The frequencies and intensities were obtained by fitting each absorbance band with a Lorentzian line shape or a Voigt line shape in the case of samples reconstituted in the $\mathrm{TFE} / \mathrm{H}_{2} \mathrm{O}$ solvent system. The frequencies used as the site energies in the local mode Hamiltonian in equation 1 were obtained from a control experiment that was performed for each solvent environment. The control experiments were designed such that there would not be any coupling between nitrile labels in the sample. In $\mathrm{H}_{2} \mathrm{O}$, the control experiment was simply a 1:1 mixture of the sequences OAK-25 (contains $\mathrm{C}^{14} \mathrm{NdU}$ ) and OAK-28 (contains $\mathrm{C}^{15} \mathrm{NdU}$ ). These are non-complimentary and thus are single 
stranded. The control experiment for the TFE/ $\mathrm{H}_{2} \mathrm{O}$ solvent environment was a dsDNA construct that contained one of each nitrile label and is shown in Figure S1 above. In order to obtain error bars for the coupling constants, $\beta$, the Hamiltonian in equation 1 was solved to reproduce the relative intensities observed in the two control experiments. The coupling constant extracted from the TFE/ $\mathrm{H}_{2} \mathrm{O}$ control experiment provides the error bars associated with all other coupling constants obtained in this study. The FTIR spectrum observed in this control is shown in Figure S3 below.

Table S2. Frequencies, Intensities and Coupling Constants.

\begin{tabular}{|l|l|l|l|l|l|l|}
\hline DNA & Solvent & $\begin{array}{l}\mathrm{E}_{\mathrm{C}}{ }^{15} \mathrm{~N} \\
\left( \pm 1.5 \mathrm{~cm}^{-1}\right)\end{array}$ & $\begin{array}{l}\mathrm{E}_{\mathrm{C}}{ }^{14} \mathrm{~N} \\
\left( \pm 1.5 \mathrm{~cm}^{-1}\right)\end{array}$ & $\mathrm{I}_{\mathrm{C}}{ }^{15}{ }_{\mathrm{N}}(\mathrm{abs})$. & $\mathrm{I}_{\mathrm{C}}{ }^{14}{ }_{\mathrm{N}}(\mathrm{abs})$. & $\beta\left(\mathrm{cm}^{-1}\right)$ \\
\hline ssDNA $^{\mathrm{a}}$ & $\mathrm{H}_{2} \mathrm{O}$ & 2214.3 & 2241.3 & 1.0 & 0.99 & -0.10 \\
\hline B-form & $\mathrm{H}_{2} \mathrm{O}$ & 2214.0 & 2240.7 & 1.0 & 0.86 & -1.3 \\
\hline A-form & TFE/ $\mathrm{H}_{2} \mathrm{O}$ & 2212.6 & 2238.6 & 1.0 & 0.60 & -3.9 \\
\hline A-form & TFE/ $\mathrm{H}_{2} \mathrm{O}$ & 2212.4 & 2237.1 & 0.96 & 1.0 & 0.3 \\
\hline
\end{tabular}

a. Control 1 in which the DNA is single stranded and no vibrational coupling is present.

b. Control 2 in which the DNA is double stranded A-form, but only one of each label is present and they are separated by $\sim 37 \AA$. 
Figure S3. The A-form dsDNA construct in TFE/ $\mathrm{H}_{2} \mathrm{O}$ which contains only one of each nitrile label. The $\mathrm{C}^{14} \mathrm{NdU}$ and $\mathrm{C}^{15} \mathrm{NdU}$ labels are separated by $\sim 37 \AA$ A and thus, are not coupled.

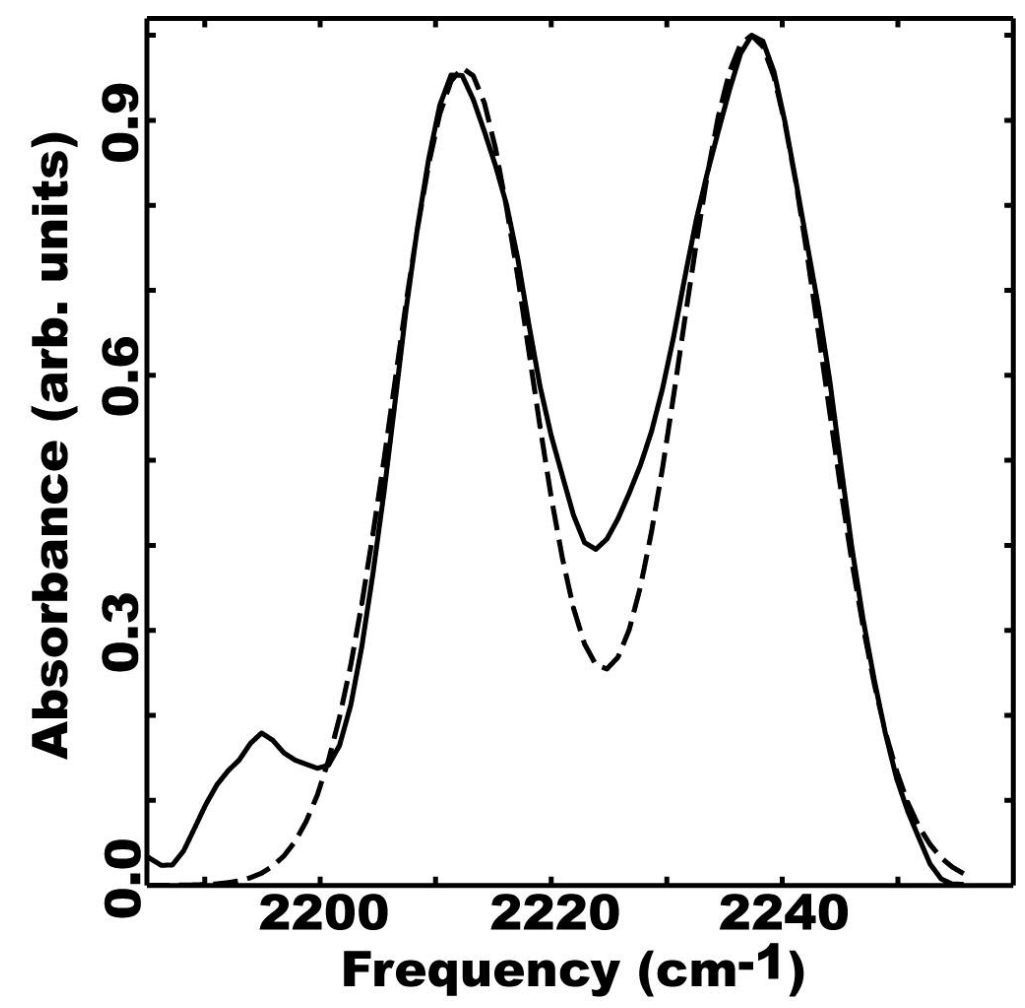

Electronic Structure Calculations. In order to develop a model of the interaction that leads to vibrational coupling between the nitrile labels, electronic structure calculations were carried out. Gaussian $03^{2}$ was used to perform a geometry optimization on a single $\mathrm{CN}$-uracil base and subsequently calculate the normal modes of the molecule using B3LYP with the 6-31G** basis set. The frequency calculations provided eigenvectors describing the nitrile stretch $\left(Q_{C N}\right)$, the transition dipole vector of the mode, and thus the oscillator strength. Using a scaling factor, $s=0.952$, the frequency calculations at this level of theory reproduce the experimental site energies, $\mathrm{E}_{\mathrm{C}}{ }^{14}{ }_{\mathrm{N}}$ and $\mathrm{E}_{\mathrm{C}}{ }^{15}{ }_{\mathrm{N}}$, of $\mathrm{C}^{14} \mathrm{NdU}$ and $\mathrm{C}^{15} \mathrm{NdU}$ in $\mathrm{H}_{2} \mathrm{O}$. The calculated transition dipole vectors yield an angle of $0^{\circ}$ relative to the $\mathrm{CN}$ bond, therefore the transition dipole lies along the $\mathrm{CN}$ bond, and an oscillator strength of $0.93 \mathrm{D} / \mathrm{A} \cdot \mathrm{amu} \mathrm{u}^{1 / 2}$. This oscillator strength is underestimated as compared to that obtained from integrating the FTIR spectrum of the individual $\mathrm{C}^{14} \mathrm{NdU}$ or $\mathrm{C}^{15} \mathrm{NdU}$ in $\mathrm{H}_{2} \mathrm{O}$, which is $1.61 \mathrm{D} / \AA \bullet \cdot \mathrm{amu}^{1 / 2}$.

\section{References}


(1) Bloomfield, V. A.; Crothers, D. M.; Tinoco, J., Ignacio Nucleic Acids: Structure, Properties, and Function; University Science Books: Sausalito, CA, 2000.

(2) Frisch, M. J.; Trucks, G. W.; Schlegel, H. B.; Scuseria, G. E.; Robb, M. A.; Cheeseman, J. R.; J. A. Montgomery, J.; Vreven, T.; Kudin, K. N.; Burant, J. C.; Millam, J. M.; Iyengar, S. S.; Tomasi, J.; Barone, V.; Mennucci, B.; Cossi, M.; Scalmani, G.; Rega, N.; Petersson, G. A.; Nakatsuji, H.; Hada, M.; Ehara, M.; Toyota, K.; Fukuda, R.; Hasegawa, J.; Ishida, M.; Nakajima, T.; Honda, Y.; Kitao, O.; Nakai, H.; Klene, M.; Li, X.; Knox, J. E.; Hratchian, H. P.; Cross, J. B.; Bakken, V.; Adamo, C.; Jaramillo, J.; Gomperts, R.; Stratmann, R. E.; Yazyev, O.; Austin, A. J.; Cammi, R.; Pomelli, C.; Ochterski, J. W.; Ayala, P. Y.; Morokuma, K.; Voth, G. A.; Salvador, P.; Dannenberg, J. J.; Zakrzewski, V. G.; Dapprich, S.; Daniels, A. D.; Strain, M. C.; Farkas, O.; Malick, D. K.; Rabuck, A. D.; Raghavachari, K.; Foresman, J. B.; Ortiz, J. V.; Cui, Q.; Baboul, A. G.; Clifford, S.; Cioslowski, J.; Stefanov, B. B.; Liu, G.; Liashenko, A.; Piskorz, P.; Komaromi, I.; Martin, R. L.; Fox, D. J.; Keith, T.; Al-Laham, M. A.; Peng, C. Y.; Nanayakkara, A.; Challacombe, M.; Gill, P. M. W.; Johnson, B.; Chen, W.; Wong, M. W.; Gonzalez, C.; Pople, J. A. Gaussian 03; Revision C.02 ed.; Gaussian Inc.: Wallingford, CT, 2004. 